\title{
PRODUCTION OPTIMIZATION AND FOOD NEEDS PROVISION DISTRIBUTION IN SOUTH HALMAHERA REGENCY, NORTH MALUKU
}

\author{
Ahmad Yunan Arifin ${ }^{1 *}$, Soemarno ${ }^{2}$, Budi Setiawan ${ }^{3}$, Sudarto $^{2}$, and \\ Amiruddin Teapon ${ }^{4}$ \\ ${ }^{1)}$ Department of Agricultural Sciences, University of Brawijaya, Indonesia \\ ${ }^{2)}$ Department of Soil Science, University of Brawijaya, Indonesia \\ ${ }^{3)}$ Department of Social Economics, University of Brawijaya, Indonesia \\ 4) Department of Soil Science, University of Khairun, Indonesia \\ "Corresponding author: ahmadyunanarifin@gmail.com
}

\begin{abstract}
Small islands have food development constraints due to their location characteristics which are dispersed and isolated. These small islands have limited capacity of land resource along with low efficiency of food distribution so that it influences sufficiency level of affordable food availability. Therefore, the aims of this research are: (1) to analyze regional food balance to fulfil food and nutrition needs; (2) to analyze the direction of food production development with small island basis; and (3) to analyze the interaction pattern of food distribution among small islands to ensure sufficiency food availability. This research was conducted in MarchDecember 2016 in South Halmahera Regency. This research design is explorative using primary and secondary data. Primary data was collected by observation results, interview, and Focused Group Discussion (FGD). The result research shows that land optimization for the development of Wetland Food Crops (TPLB), Dry land Food Crops (TPLK), and Annual Food crops (TPT) are able to fulfil South Halmahera people's food needs and its land availability surplus is 5,159.2; 34,834.9 and 21,971.0 ha. Interaction pattern among small island is needed for food availability from TPLK and TPLB in Bacan and Makian Small Island. Interaction pattern among small islands is needed for rice availability in all sub district of South Halmahera by optimize land resource potential, system recovery of land transportation and port warehouse in every small islands, empowerment of citizen ship in rice distribution from small island centre to every sub districts as well as TPLK and TPT distribution from nearby sub district in the same small island.
\end{abstract}

Keywords: archipelago, land resource, transportation

\section{INTRODUCTION}

Food is a basic human need to live and deserve a good quality of life. According to the food importance, thus food availability which has sufficient nutrition and affordable is needed to be ensured by optimization food resource diversification and local culture in every region (Sudaryanto and Rusastra, 2008; Azahari, 2008). This strategy is relevant in reaching food security development in Indonesia which has archipelago characteristic with food supply potential and transportation system which is different in each region (Manuwoto dan Martianto, 2008).

Food security development program in Indonesia has been successfully increasing national food availability. However, it is not a good measurement in ensuring food security status in each region (Bantacut, 2013). The result of region mapping shows that 100 regions/cities are categorized as very low food security by the fact that $80 \%$ of them are located in East Indonesia Region. This region are focused on the small islands: NTB, NTT, Maluku, North Maluku, Papua, and West Papua and there are 50 regencies/cities. Availability factor of food quantity and type, food access ability, and affordable food price are being obstacles in reaching food security status in East Indonesia region (Rachmaningsih, 2012).

East Indonesia is dominated by small island area which is dispersed and isolated. It will affect the efficiency of affordable food availability 
(Connell, 2015).Small island has land capacity limitation which can be beneficial so that it influences food and non-food production activity scale and type (Hay and Mimura, 2013). For instance, food production level in North Maluku has not meet people's food needs, except for tuber crops food, and animal protein while for paddy/cereals, nuts, vegetable, fruit and spices as much as $39 ; 47 ; 17$ and $2 \%$ in order.

Small island also has impacts in the limitation of transportation system availability to serve product distribution from and to dispersion islands (Pelling and Uitto, 2001). Transportation obstacle affects a high production cost which has to be spent per transportation unit so that it influences people ability in optimizing any business opportunities (Purwaningsih, 2008). Because of the low business utilization, people's income is also low. In average, it is only IDR 3,429,000 for people's income in NTB, NTT, Maluku, North Maluku, Papua, and West Papua while IDR $9,572,000$ is national income (BPS, 2013). For that reason, these small islands has low characteristic of provision ability and food economic access due to land resource limitation and business opportunity utilization (Adrianto and Matsuda, 2004).

Transportation system which is limited will also affect the efficiency of food distribution in each dispersed islands. Distance, increasing in fuel price, and distribution availability are obstacles in reaching affordable food price (Ridhwan, Karlina, dan Yanfitri, 2012). Compared to any other region, food price in East Indonesia has relatively higher price, except for rice commodity. Maluku and North Maluku Province has higher different price in cooking oil and red chilli: IDR 2400,- and IDR 8,000 while higher price for onion and sugar is in Papua-West Papua: IDR 9500,- and IDR 1200,(Ridhwan, dkk, 2012). Therefore, people who live in East Indonesia have high pressure in fulfilling food needs due to low income and unaffordable food price.

South Halmahera is one of regions which is categorized as low food security in East Indonesia (BKP, 2009). It consists of Bacan Island, Kasiruta Island, Mandioli Island, Obi Island, Bisa Island, Gura Ici Islands, Makian Islands, Batang Lomang Islands, dan Joronga Islands. Sustainability food security development in South Halmahera Islands are done by the approach of production optimization and food distribution with small island basis to make sure affordable food availability and food access ability for people. The strategy of food production optimization concerns on land ability and compatible in order to maintain sustainable resource utilization and ecological function as well as the ability of independently fulfilling food needs (Dahuri, 2008; Widiatmaka, et al, 2015). Distribution optimization strategies are done by optimizing region production ability so that food distribution pattern which is efficient with intra and among small islands is able to be reached (Lokollo, 2012). In this case, food needs have expenditure consumption allocation as much as (50-60\%) compared to any other needs. Thus, food production optimization activities are alternative strategy in increasing people's income in order to have good food access (Bantacut, 2013).

The aims of this research are: (1) to analyze regional food balance to fulfil food and nutrition needs; (2) to analyze the direction of food production development with small island basis; and (3) to analyze the interaction pattern of food distribution among small islands to ensure sufficiency food availability.

\section{METHODS}

This research was conducted in South Halmahera Regency and geographically, its coordinate lies on $126^{0} 45^{\prime}-129^{0} 30^{\prime} \mathrm{BT}$ dan $0^{0} 30^{\prime} \mathrm{LS}-2^{0} 00^{\prime} \mathrm{LU}$ with $22 \%$ of land area (Picture 1 ) as following: 

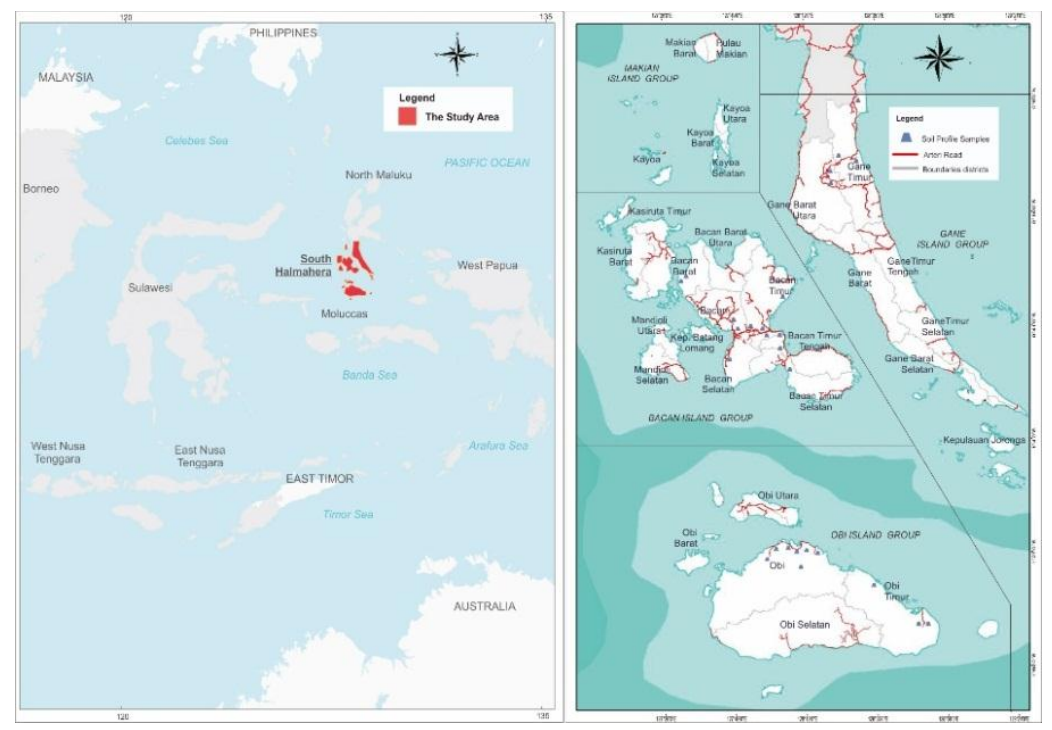

Figure 1. Research location in South Halmahera and North Maluku

This area is dominated by small dispersed small islands. Obi Island is the largest island which has $2,543 \mathrm{~km}^{2}$ of land area so that all South Halmahera Regency is categorized as small island criteria, except Gane which is located in the Halmahera big island.

The characteristics of South Halmahera people's distribution are $21 \%$ in Obi Islands, $16 \%$ in Makian Islands, $20 \%$ in Gane Islands, $32 \%$ in Bacan Island, and $12 \%$ in the outside of Bacan Island. South Halmahera is dominated by the mountains (>40\%) as much as 218.462 ha $(26.8 \%)$. In this study, South Halmahera Regency is divided by 4 island groups: Bacan, Gane, Obi dan Makian.

\section{Ideal Balance of Food Needs-Availability}

Food Needs-Availability Balance is identification of food crops land area status that is available towards land area needs to produce nutritional foods. Food needs are calculated refers to the national index of energy availability (IEA) which is $2,200 \mathrm{kcal} / \mathrm{capita} /$ day. Energy contribution for each food groups in fulfilling total energy needs per capita/day is calculated by using Desirable Dietary Pattern (DDP) (Hardinsyah, Madanijah dan Baliwati, 2002). Desirable Dietary Pattern (DDP) shows food consumption diversification according to energy contribution in each food groups (Table 1).

Food needs are calculated by the assumption of constant growth rate, constant food crops's productivity, and food needs are only for people's consumption, as well as age composition ais close to national people's composition (Absari, 2007; Sumarlin, 2009). The total people in South Halmahera Regency in 2021 are predicted as much as 247,571 with $2.1 \%$ of growth rate.

Food availability is calculated according to the total calorie availability from the total land area for food crops that can be produced and consumed in certain time. The total calorie availability per year is measured by the energy composition per $100 \mathrm{gr}$ in each food crops and production conversion factor (ton) to kcal to get total energy that is able to be consumed by people (Departemen Kesehatan, 1996). Production assumption for each food crops is remain used to identify the total availability and land needs from the data of food crops production availability and needed to reach people's recommended dietary allowances.

The analysis of Food Needs-Availability Balance is done for five food groups: (1) paddy/cereals, (2) tuber crops, (3) nuts, (4) spices, (5) vegetables and fruits. The result of this analysis will provide deficit information of land balance that has to be developed to produce food crops by optimizing land resource. Crops selection in land resource optimization concerns on consumption pattern and food crops production potential that has been developed in South Halmahera. 
Table 1. Food Groups Proportion and Food Needs Standards According to DDP Calculation

\begin{tabular}{|c|c|c|c|c|c|c|}
\hline \multirow[b]{2}{*}{ No } & \multirow[b]{2}{*}{ Food groups } & \multirow[b]{2}{*}{$\begin{array}{c}\text { Proportion } \\
(\%)\end{array}$} & \multicolumn{2}{|c|}{ Energy Needs Standard } & \multicolumn{2}{|c|}{ Needs } \\
\hline & & & $\begin{array}{c}\text { kcal/cap/ } \\
\text { day }\end{array}$ & $\begin{array}{c}\mathrm{kcal} / \mathrm{cap} / \\
\text { year }\end{array}$ & $\begin{array}{c}\text { gram/cap/ } \\
\text { day }\end{array}$ & $\begin{array}{c}\text { gram/cap/ } \\
\text { year }\end{array}$ \\
\hline 1 & Paddy/Cereals & 50 & 1,100 & 401,500 & 306 & 112 \\
\hline 2 & Tuber Crops & 6 & 132 & 48,180 & 93 & 34 \\
\hline 3 & Animal protein & 12 & 264 & 96,360 & 128 & 47 \\
\hline 4 & Oil and fat & 10 & 220 & 80,300 & 25 & 9 \\
\hline 5 & Oily Seeds & 3 & 66 & 24,090 & 10 & 4 \\
\hline 6 & Nuts & 5 & 110 & 40,150 & 29 & 11 \\
\hline 7 & Sugar & 5 & 110 & 40,150 & 30 & 11 \\
\hline 8 & Vegetable and Fruit & 6 & 132 & 48,180 & 278 & 101 \\
\hline 9 & Spices & 3 & 66 & 24,090 & 64 & 23 \\
\hline & Total & 100 & 2,200 & 803,000 & & \\
\hline
\end{tabular}

\section{Land Availability}

Land used optimization is a way to increase food crops production to fulfil food needs deficit. Land utilization prediction is used by identifying land availability according to forest used and land used status as well as identifying land compatibility and priority to improve food crops.

Land resource availability is identified on sub district scal is able to be used. While protected forest (HL), production forest (HP), limited production forest (HPT), nature reserve forest (HSA, and water body (TA) is not.

Along with cultivation region and conversion production forest development, so land is used for people's activities. So those, land adjustment in these forests need to be done in order to increase food crops production (Mustafril, et al, 2009). Land used status classifications which are able to be used including open land, grazing land, and shrubbery. While habitation, industrial activities, transportasi availability, crops land, tree crops, primary forest, and mangrove are not.

\section{Land Used Compatibility and Priority}

Land used compatibility is identified by land evaluation by comparing the requirement of biophysics growth with land characteristic (Djaenudin, dkk, 2003). It is determined by the groups of wet land crops (paddy), dry land crops (tomato), and annual crops (durian). Land compatibility evaluation results land dispersion category: strongly compatible (S1), compatible (S2), incompatible (S3), strongly incompatible (N). $\mathrm{S} 1, \mathrm{~S} 2$, and $\mathrm{S} 3$ are for the land who has low, high enough, and high limitation factor so it affects input rate to increase land productivity according to certain plant development (Widiatmaka, et al,2014). While for $\mathrm{N}$, it has very high limitation factor so it is not worth to be used for all crops development.

Land evaluation results indicate same land compatibility in a land location so that food crops development priority is needed (Mustafril, et al, 2009). Those priorities are: Wetland Food Crops
(TPLB) as forst priority, Dry land Food Crops (TPLK) as second priority, and Annual Food crops (TPT) as third priority.

\section{Optimum Land Used}

Land used optimization to meet food needs results information related to optimal land needs balance

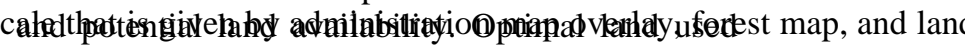
projection is identified according to optimum land used ability that can be produced in every planting period per year for each food crops. Land used optimization is TPLB, TPLK, and TPT land used according to food crops.

Potential land area for each crop is proportional composition for ideal land needs over land needs for each food crops. The availability proportion of paddy, maize, cassava, peanut, mug bean, soybean, eggplant, tomato, chilli, and onion are $19.2 ; 2.5 ; 7.0 ; 5.5 ; 7.6 ; 6.1 ; 7.1 ; 5.3 ; 16.9 ; 13.9$; and $8.4 \%$ in order from TPLK's land needs. Availability proportion for mango, durian, and banana are as much as 50; 28; and 22\% from TPT's land needs.

\section{Food Distribution}

Food distribution is improved by transportation system availability which can be reached intra and among small islands interaction pattern. It is for making sure that food availability is sufficient according to production availability for each area.

Food distribution study is descriptively done by doing an observation in transportation network characteristic that supports intra and among small islands food distribution (Jinca, 2009). Some used variable in this observation is: i). Transportation needs volume and location according to food needs and availability balance, ii) sea transportation availability among small islands, iii) Route Distribution structure between regions, iv) ship quantity, frequency, and capacity according to shipping route. 


\section{RESULTS AND DISCUSSION}

\section{Food Needs Land Balance}

The information of Land Balance Status to meet food needs-availability is a reference in food provision planning. Land needs-provision balance status according to food groups is showed in Table 2. The availability of actual planting land for food crops in the regency cannot fulfil ideal food needs in 2021: paddy, nuts, vegetables, and spices. Paddy rice in dry land, maize, tuber crops, animal protein, and fruits has self-sufficient level as much as 149; $412 ; 711 ; 185 ; 533 ; 598$; and $122 \%$ and these groups has the surplus of planting land availability. Fish has the biggest contribution in fulfilling animal protein food groups with total consumption of $122.7 \mathrm{gr} /$ days while livestock has $3.0 \mathrm{gr} /$ days (Susenas, 2014).

Table 2. Status of Actual Planting Land Availability and Food Needs Projection to Fulfil Ideal Food Needs Deficit in 2021

\begin{tabular}{clcccc}
\hline No & Food Groups & Land Needs & $\begin{array}{c}\text { Planting Land } \\
\text { Availability }\end{array}$ & Gap & $\begin{array}{c}\text { Has Fulfilled } \\
\text { or not }\end{array}$ \\
\hline Paddy/cereals groups & & & & No \\
\hline 1 & Paddy rice & 3,200 & 611 & 2,589 & Yes \\
2 & Upland Rice & 207 & 309 & 102 & Yes \\
3 & Maize & 107 & 440 & 333 & Yes \\
\hline Tuber Crops & & & & 1,815 & No \\
\hline 4 & Cassava & 297 & 2,112 & 57 & No \\
\hline Nuts & & & & 251 & No \\
\hline 5 & Peanut & 236 & 179 & 222 & No \\
6 & Mug bean & 325 & 74 & & No \\
7 & Soybean & 261 & 39 & 284 & Yes \\
\hline Vegetables & & & & 226 & Yes \\
\hline 8 & Eggplant & 302 & 18 & & Yes \\
9 & Yard long Bean & 226 & 0 & 147 & No \\
10 & Tomato & 718 & 39 & 416 & No \\
\hline Fruits & & & & 364 & Yes \\
\hline 11 & Mango & 172 & 319 & 188 &
\end{tabular}

\section{Land Used and Cover}

Land used and cover are dominated by secondary forest, tree crops/mixed plantation, and shrubbery (Table 3 and Picture 2). Food production optimizing can be done in shrubbery, grazing land, open land, and secondary forest. Shrubbery and grazing land used in South Halmahera is largely found in Obi, 46,545 ha $(52 \%)$ and 11,444 ha $(93 \%)$. Secondary forest land is relatively large in every small island, except Makian while the largest paddy field is located in Gane Timur Sub District, 2,645 ha (99\%). Timur. 
Table 3. Land Used and Cover

\begin{tabular}{|c|c|c|c|c|c|c|c|}
\hline \multirow[t]{2}{*}{ No } & \multirow[t]{2}{*}{ Land Cover } & \multirow{2}{*}{$\begin{array}{c}\text { Bacan } \\
\text { (ha) }\end{array}$} & \multirow{2}{*}{$\begin{array}{c}\text { Gane } \\
\text { (ha) }\end{array}$} & \multirow{2}{*}{$\begin{array}{l}\text { Obi } \\
\text { (ha) }\end{array}$} & \multirow{2}{*}{$\begin{array}{c}\text { Makian } \\
\text { (ha) }\end{array}$} & \multicolumn{2}{|c|}{ Total } \\
\hline & & & & & & Ha & $\%$ \\
\hline 1 & Water body & 467 & 645 & 2,251 & 21 & 3.383 & 0.4 \\
\hline 2 & Barrier reef & 0 & 11 & 0 & 0 & 11 & 0.0 \\
\hline 3 & Habitation & 1,188 & 597 & 427 & 427 & 2,639 & 0.3 \\
\hline 4 & Paddy Field & 0 & 2,204 & 0 & 0 & 2,204 & 0.3 \\
\hline 5 & Upland Field & 7 & 0 & 3,290 & 0 & 3,297 & 0.4 \\
\hline 6 & Tree Crops & 55,553 & 49,498 & 44,645 & 13,709 & 163,405 & 21.0 \\
\hline 7 & Open Land & 26 & 81 & 36 & 64 & 207 & 0.0 \\
\hline 8 & Grazing Land & 650 & 164 & 11,444 & 0 & 12,259 & 1.6 \\
\hline 9 & Shrubbery & 23,479 & 15,035 & 46,545 & 5,024 & 90,082 & 11.6 \\
\hline 10 & Mangrove & 5,806 & 8,864 & 4,568 & 2,107 & 21,345 & 2.7 \\
\hline 11 & Swamp & 128 & 51 & 31 & 12 & 222 & 0.0 \\
\hline 12 & Secondary Forest & 143,352 & 165,614 & 143,384 & 4 & 452,353 & 58.1 \\
\hline 13 & Primary Forest & 0 & 0 & 27,430 & 0 & 27,430 & 3.5 \\
\hline & Total & 230,656 & 242,762 & 284,052 & 21,367 & $\mathbf{7 7 8 , 8 3 7}$ & 100 \\
\hline
\end{tabular}

land and conversion production forest. The total

\section{Forest Area Status}

In line with the determination of Forest and Waters Area in North Maluku Province (Utara (SK No.302/menhut-II/2013) so potential land land area which is available is 270,074 ha $(33.1 \%$ of land total area) with the least ones in Makian small island $(12,714 \mathrm{ha})$ or $4,7 \%$ of the total land availability to improve food crops are cultivation

area (Table 7 and Picture 2b).

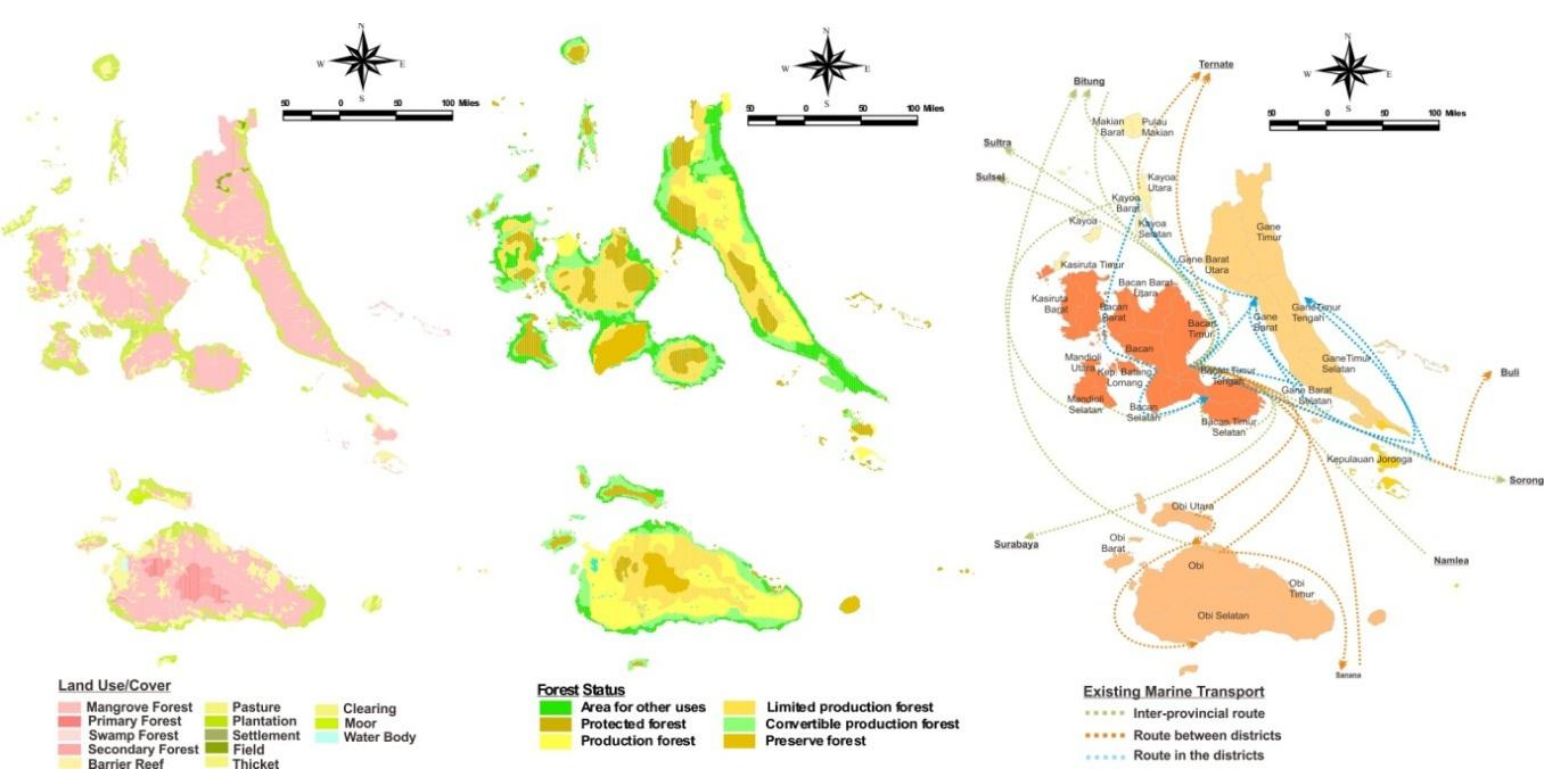

Figure 2. Map of: (a) land cover, forest status, and existing marine transport, of South Halmahera

Tabel 4. Forest Use

\begin{tabular}{rlrrrrrrrr}
\hline No & $\begin{array}{l}\text { Small } \\
\text { Island }\end{array}$ & $\begin{array}{c}\text { Total Land } \\
\text { Area }\end{array}$ & \multicolumn{1}{c}{ APL } & HPK & HL & HP & HPT & HSA & TA \\
\hline 1 & Obi & 284,052 & 24,518 & 44,787 & 15,461 & 99,433 & 78,166 & 19,451 & 2,236 \\
2 & Bacan & 230,656 & 52,351 & 32,995 & 53,379 & 7,018 & 61,794 & 22,673 & 448 \\
3 & Makian & 21,367 & 3,679 & 7,895 & 8,339 & - & 1,431 & - & 23 \\
4 & Gane & 242,762 & 68,480 & 30,682 & 41,197 & 66,503 & 34,697 & - & $1 ., 202$ \\
\hline \multicolumn{2}{c}{ Jumlah } & $778 ., 837$ & 149,028 & 116,358 & 118,376 & 172,954 & 176,089 & 42,123 & 3,909 \\
\hline
\end{tabular}

Note: APL (Another Land Use), HPK (conversion production forest), HL (protected forest), HP (production forest), HPT (limited production forest), HSA (nature reserve forest), and TA (water body). 
According to the land use/cover evaluation in APL so potential land availability and reserve land I for improving food crops is located on Gane, Bacan, Obi, and Makian Small Island (15,958; 12,530; and 5,225 and 202 ha). Reserve land II has big contribution in providing land to develop food crops in Makian Small Island as much as 833 ha.

\section{Existing Transportation}

Land transportation has been built to fulfil movement needs in land use. However, transportation availability in South Halmahera tends to be for government and people economic activities. Around $46,5 \%$ of the street availability is in Bacan Island as the capital of regency (BPS, 2015). On the other hand, low accessibility is on cultivation land. Gane Timur Sub District as the central production of paddy has broken street so that farmers have difficulties in producing and distributing their production. Rice production and distribution orientation are only done for fulfilling internal and nearby area needs. Gane Timur has 603,7 ha or $27 \%$ paddy planting area of the total potential paddy field land (BPS,2013).

Besides that, in order to connect the small islands which are relatively dispersed so port has been built. It has facilities to serve transportation route among the small islands (Ralahalu, dkk,
2013). The intensity of sea transportation route in Gane, Makian, dan Obi Island are 84, 56, 48 dan 38 trip/month. Figure 2.

According to the existing sea transportation system, all of small islands does not get regularly sea transportation services for instance Obi Timur, Obi Barat, Gane Timur Tengah, Gane Timur Selatan, Mandioli Selatan, Mandioli Utara, Kasiruta Barat dan Kasiruta Timur Sub Districts. In these regions, people has initiative in serving their own tradtional ship. The ratio of ship ownership according to the total population in each small island is 40 people/ship in average. This ship can be used for distributing food in each small island.

\section{Identification of Compatibility and Priority Land Use}

TPLB land use evaluation results land total of compatible (S2), incompatible (S3) as much as 217 dan 5.544,3 ha. Land limitation factors for compatible (S2) status are oxygen availability limitation factors (oa), nutrient retention (nr), nutrient availability (na), erosion hazard (eh), and land preparation (lp).

Table 8. Compatibility and Priority Land Use

\begin{tabular}{|c|c|c|c|c|}
\hline \multirow{2}{*}{$\begin{array}{c}\text { Land } \\
\text { Categories }\end{array}$} & \multirow{2}{*}{$\begin{array}{c}\text { Land Use } \\
\text { Type }\end{array}$} & \multirow{2}{*}{$\begin{array}{c}\text { Land } \\
\text { Compatibility } \\
\text { Level }\end{array}$} & \multicolumn{2}{|c|}{ Total } \\
\hline & & & $\mathrm{Ha}$ & $\%$ \\
\hline \multirow{8}{*}{$\begin{array}{l}\text { Potential } \\
\text { Land }\end{array}$} & \multirow{3}{*}{ TPLK } & $\mathrm{S} 2$ & 4,042 & 4 \\
\hline & & S3 & 2,027 & 2 \\
\hline & & $\mathrm{S} 2$ & 0 & 0 \\
\hline & \multirow[t]{3}{*}{ TPT } & S3 & 2,024 & 2 \\
\hline & & $\mathrm{N}$ & 1,047 & 1 \\
\hline & & S2 & 217 & 0 \\
\hline & \multirow[t]{2}{*}{ TPLB } & S3 & 223 & 0 \\
\hline & & $\mathrm{N}$ & 276 & 0 \\
\hline \multirow{8}{*}{$\begin{array}{l}\text { Reserve } \\
\text { Land II } \\
\text { (HPK) }\end{array}$} & \multirow{3}{*}{ TPLK } & $\mathrm{S} 2$ & 6,017 & 6 \\
\hline & & S3 & 16,120 & 16 \\
\hline & & $\mathrm{S} 2$ & 0 & 0 \\
\hline & \multirow[t]{3}{*}{ TPT } & S3 & 14,469 & 14 \\
\hline & & $\mathrm{N}$ & 30,691 & 30 \\
\hline & & S2 & - & - \\
\hline & \multirow[t]{2}{*}{ TPLB } & S3 & 2,370 & 2 \\
\hline & & $\mathrm{N}$ & 5,522 & 5 \\
\hline \multirow{8}{*}{$\begin{array}{l}\text { Reserve } \\
\text { Land I } \\
\text { (Secondary } \\
\text { Forest) }\end{array}$} & \multirow{3}{*}{ TPLK } & S2 & 1,098 & 1 \\
\hline & & S3 & 3,394 & 3 \\
\hline & & S2 & 0 & 0 \\
\hline & \multirow[t]{3}{*}{ TPT } & S3 & 5,569 & 5 \\
\hline & & $\mathrm{N}$ & 4,852 & 5 \\
\hline & & S2 & - & - \\
\hline & \multirow[t]{2}{*}{ TPLB } & S3 & 2,898 & 3 \\
\hline & & $\mathrm{N}$ & 1,107 & 1 \\
\hline
\end{tabular}


According to land characteristics, soil chemical conditions need to be enhancement and improved, including soil acidity $(\mathrm{pH})$, soil cation exchange capacity, organic materials and nitrogen $(\mathrm{N})$, as well as calium through soil calcification and fertilizer application. Besides that, continuous water availability is becoming a boundary factor in paddy improvement because farmers depend on semi technical irrigation. Government supports are needed in building good irrigation system to manage water availability and distribution (BPTP Maluku Utara, 2015).

TPLK land compatibility evaluation results compatible availability (oa), nutrient retention (nr), nutrient availability (na), erosion hazard (eh), and land preparation (lp) are becoming land boundary factors. While in S3 level, there are rooting condition (rc), nutrient retention (nr), nutrient availability (na), erosion hazard (eh), and land preparation (lp). Because of low rainfall intensity, around 2,199.2 mm/year, there is lack of water availability in TPLK development. Time and cropping pattern management as well as water storage building is needed (Arsyad, 2012). Planting period of TPLK food crops in dry land should be done in the beginning of rainy season, November until July. Food and horticulture crops that can be developed are maize+peanut-tomato/red chilli-cassava.

TPLK land compatibility evaluation also results soil fertility limitation factors and erosion hazard. It is influenced by soil cation exchange capacity, soil organic materials, nitrogen and calium availability so that soil calcification, organic material and fertilizer application are needed. Erosion hazard can be triggered by land slope: flat $(1-3 \%)$ and medium $(8-15 \%)$ and open land is dominated. Furthermore, it has bad impact in decreasing soil fertility and it will cause low productivity due to nutrient and organic material loss (Pimentel and Burgess, 2013). That is why soil conservation is needed for example terrace, intercropping application, and planting according to soil contour (Widiatmaka, et al, 2015).

The evaluation of TPT land compatibility results $\mathrm{S} 2$ and $\mathrm{S} 3$ as much as 0 and 22.062 ha. In $\mathrm{S} 3$, rooting condition (rc), nutrient retention (nr), nutrient availability (na), erosion hazard (eh), and land preparation (lp) are becoming land limitation factors. In this case, TPT development focuses on the land which its slope is $8-15 \%-15-25 \%$. The suggestion for $8-15 \%$ land slope is to apply mixed farming among tree, food, and horticulture crops with its main crops is coconut. While for $15-25 \%$ of land slope is to apply mixed farming with tree crops. Soil fertilizer obstacle needs to get land management for example calcification, organic material and fertilizer application, especially in the beginning of planting period. In order to solve long dry season, retention basin is needed related to the lack of water problem.

\section{Optimum Land Use According to Food Crops}

Total projection of optimum land use for TPLB, TPLK, and TPT can fulfil optimum land needs to

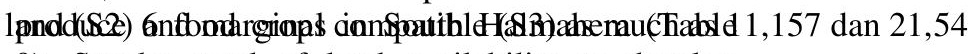

9). Surplus total of land availability to develop TPLB in Gane Timur Sub District is as much as $5,159.2$ ha. It considers on rice field area and existing land area which does not produce, as much as 603.7 and 2,645.0 ha so that ideal land area needs is 547.7 ha. Availability of land area for optimizing TPLK and TPT development land can meet optimal land needs in South Halmahera, as much as 34,834.9 and 21,971.0 ha. However, there is deficit in fodd crops fulfillment balance from land optimize result to develop TPLK and TPT in sub district area.

Makian small island has TPT land deficit as much as 7.1 ha so that distribution of fruit crops from nearby sub district in the same small island is needed. Makian Barat Sub District has surplus on the availability of potential TPT land in cultivation area as much as 29 ha so this sub district can be alternative for being distributor for potential land needs deficit in Makian Sub District.

Land Availability status of TPLK land potential in fulfilling ideal land needs shows variations in the same sub district. All sub district in Obi and Gane Small Islands are able to fulfil Ideal land needs for TPLK from potential land in every sub district. TPLK land potential availability in Bacan Selatan, Kayoa, Kayoa Selatan Sub Districts, and Makian Island are not able to fulfill their ideal TPLK land needs. Their own deficits are 123.9; 59.6; 8.6; dan 93.7 ha. On the other hand Bacan Selatan Sub District can fulfil its TPLK potential land availability from Bacan timur Selatan Sub District which has 1.499,9 ha. TPLK potential land availability in Makian, Kayoa dan Kayoa Selatan Island has deficit as much as 93.7; 59.6 dan 8.6 ha that can be fulfilled form that of Kayoa Utara Sub Dsictrict which has 165 ha of land availability surplus. 


\begin{tabular}{|c|c|c|c|c|c|c|}
\hline \multirow{2}{*}{$\begin{array}{c}\text { Food } \\
\text { Groups }\end{array}$} & \multirow[t]{2}{*}{ Parameter } & \multicolumn{4}{|c|}{ Small Island } & \multirow[t]{2}{*}{ Total } \\
\hline & & Obi & Bacan & Kayoa & Gane & \\
\hline \multirow{3}{*}{ Paddy Rice } & Ideal Land Needs $(\mathrm{Ha})$ & 631.3 & $1,416.7$ & 521.4 & 19,6 & $547.7 *$ \\
\hline & Potential Land Availability (Ha) & - & - & - & $5,707.50$ & $5,707.50$ \\
\hline & Land Balance (Ha) & - & - & - & $5,688.50$ & $5,159.20$ \\
\hline \multirow{3}{*}{$\begin{array}{l}\text { Upland } \\
\text { Rice }\end{array}$} & Ideal Land Needs (Ha) & 0 & 0 & 0 & 0 & $\mathbf{0}$ \\
\hline & Potential Land Availability (Ha) & 3,621 & 1,379 & 82 & 1,196 & 6,278 \\
\hline & Land Balance (Ha) & 3,621 & 1,379 & 82 & 1,196 & 6,278 \\
\hline \multirow[t]{3}{*}{ Maize } & Ideal Land Needs (Ha) & 0 & 0 & 0 & 0 & $\mathbf{0}$ \\
\hline & Potential Land Availability (Ha) & 472 & 180 & 11 & 156 & 817 \\
\hline & Land Balance (Ha) & 472 & 180 & 11 & 156 & 817 \\
\hline \multirow[t]{3}{*}{ Cassava } & Ideal Land Needs (Ha) & 0 & 0 & 0 & 0 & $\mathbf{0}$ \\
\hline & Potential Land Availability (Ha) & 1,320 & 503 & 30 & 436 & 2,289 \\
\hline & Land Balance (Ha) & 1,320 & 503 & 30 & 436 & 2,289 \\
\hline \multirow[t]{3}{*}{ Peanut } & Ideal Land Needs $(\mathrm{Ha})$ & 44 & 72 & 16 & 0 & 131 \\
\hline & Potential Land Availability (Ha) & 1,037 & 395 & 23 & 343 & 1,798 \\
\hline & Land Balance (Ha) & 993 & 323 & 8 & 343 & 1,667 \\
\hline \multirow[t]{3}{*}{ Mug bean } & Ideal Land Needs (Ha) & 63 & 125 & 49 & 14 & 251 \\
\hline & Potential Land Availability (Ha) & 1,433 & 546 & 51 & 473 & 2,504 \\
\hline & Land Balance (Ha) & 1,370 & 421 & 3 & 460 & 2,254 \\
\hline \multirow[t]{3}{*}{ Soybean } & Ideal Land Needs (Ha) & 54 & 110 & 42 & 17 & 222 \\
\hline & Potential Land Availability (Ha) & 1,150 & 438 & 43 & 380 & 2,012 \\
\hline & Land Balance (Ha) & 1,097 & 328 & 1 & 363 & 1,790 \\
\hline \multirow[t]{3}{*}{ Eggplant } & Ideal Land Needs $(\mathrm{Ha})$ & 58 & 126 & 45 & 55 & 285 \\
\hline & Potential Land Availability (Ha) & 1,339 & 510 & 47 & 442 & 2,339 \\
\hline & Land Balance (Ha) & 1,281 & 384 & 2 & 387 & 2,054 \\
\hline \multirow{3}{*}{$\begin{array}{c}\text { Yard long } \\
\text { Bean }\end{array}$} & Ideal Land Needs (Ha) & 46 & 98 & 36 & 45 & 226 \\
\hline & Potential Land Availability (Ha) & 1,000 & 381 & 38 & 330 & 1,748 \\
\hline & Land Balance (Ha) & 953 & 283 & 2 & 285 & 1,522 \\
\hline \multirow[t]{4}{*}{ Tomato } & Ideal Land Needs $(\mathrm{Ha})$ & 144 & 292 & 81 & 135 & 651 \\
\hline & Potential Land Availability (Ha) & 3,187 & 1,214 & 84 & 1,053 & 5,538 \\
\hline & Land Balance (Ha) & 3,044 & 922 & 3 & 918 & 4,887 \\
\hline & Ideal Land Needs $(\mathrm{Ha})$ & 0 & 0 & 9.1 & 25.4 & 34.5 \\
\hline \multirow[t]{2}{*}{ Mango } & Potential Land Availability (Ha) & 217.5 & $7,898.5$ & 73.5 & 2,842 & $11,031.5$ \\
\hline & Land Balance (Ha) & 217.5 & $7,898.5$ & 64.4 & $2,816.6$ & 10,997 \\
\hline \multirow{3}{*}{ Durian } & Ideal Land Needs (Ha) & 0 & 0 & 15.3 & 19.1 & $\overline{34.4}$ \\
\hline & Potential Land Availability (Ha) & 121.8 & $4,423.2$ & 41.2 & $1,591.5$ & $6,177.7$ \\
\hline & Land Balance (Ha) & 121.8 & $4,423.2$ & 25.9 & $1,572.4$ & $6,143.3$ \\
\hline \multirow{3}{*}{ Banana } & Ideal Land Needs $(\mathrm{Ha})$ & 14.4 & 0 & 8.8 & 0 & 23.2 \\
\hline & Potential Land Availability (Ha) & 95.7 & $3,475.4$ & 32.3 & $1,250.5$ & $4,853.9$ \\
\hline & Land Balance (Ha) & 81.3 & $3,475.4$ & 23.5 & $1,250.5$ & $4,830.7$ \\
\hline \multirow[t]{3}{*}{ Chili } & Ideal Land Needs $(\mathrm{Ha})$ & 105 & 52 & 77 & 50 & 284 \\
\hline & Potential Land Availability (Ha) & 2,622 & 998 & 78 & 866 & 4,564 \\
\hline & Land Balance (Ha) & 2,517 & 946 & 1 & 816 & 4,280 \\
\hline \multirow[t]{3}{*}{ Onion } & Ideal Land Needs (Ha) & 73 & 154 & 57 & 57 & 340 \\
\hline & Potential Land Availability (Ha) & 1,584 & 603 & 59 & 523 & 2,770 \\
\hline & Land Balance (Ha) & 1,511 & 449 & 2 & 467 & 2,430 \\
\hline \multirow[t]{3}{*}{ Total } & Ideal Land Needs (Ha) & 587 & 1,029 & 401 & 373 & 2,389 \\
\hline & Potential Land Availability (Ha) & 18,766 & 7,147 & 545 & 6,199 & 32,657 \\
\hline & Land Balance (Ha) & 18,179 & 6,118 & 144 & 5,826 & 30,267 \\
\hline
\end{tabular}


Food Distribution and Production Optimization Food disribution among small island needs to fulfil balance deficit on food needs fulfilment (Picture 3). This distribution is needed for rice needs fulfilment. Rice is distributed in the production centre in Gane Timur Sub District to rice storage centre in every small islands. Rice storage is done by empowering port warehouse so that rice distribution can be done with economic volume from production centre, considering rice demand frequency in each sub district is relatively low.

Then, rice distribution from storage centre to every small island is done by optimizing sea transportations ervice by the ships. Transportation mode will be determined according to the demand volume in each storage place (Ralahalu, dkk, 2013).

Considering that rice field location is in Gane Island, transportation system provision that supports transportation mode integration is needed. However, it needs to be improved for rice production in South Halmahera especially for land transportation system. So that it will be easy to move the products with low transportation cost.

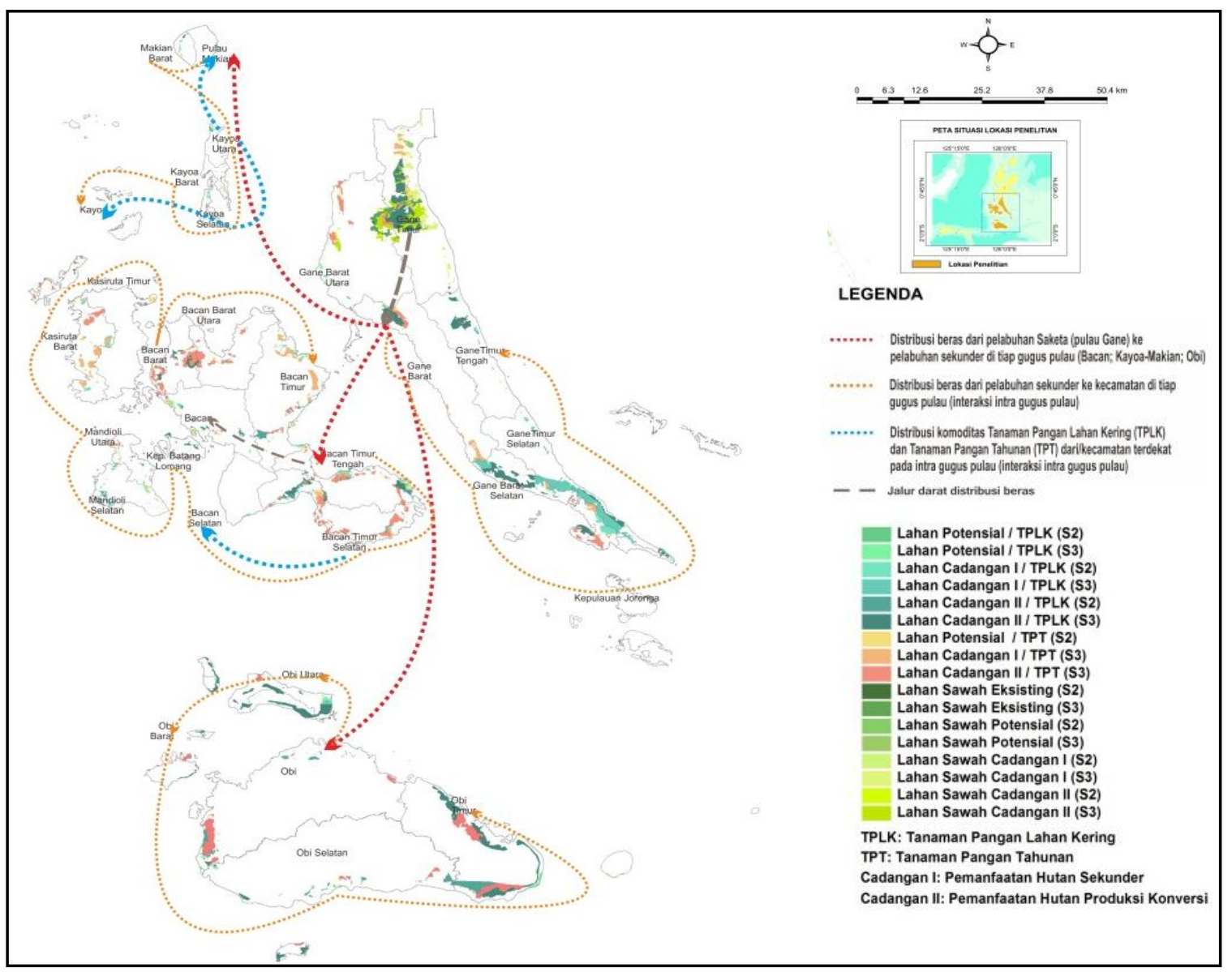

Figure 3. Food Distribution and Production Optimization

Distribution among Makian and Bacan small islands is done to cover deficit of land needsavailability balance for TPLK and TPT. Bacan Selatan, Kasiruta Timur, Kayoa, Makian Barat and Makian Island has limitation in fulfilling this so that they need food supply from any other sub districts in the same small islands. Kayoa Utara Sub District can become alternative supplier to Kayoa and Makian Barat Sub District while that of Makian island con be covered by Kayoa Barat Sub District. Bacan Island and Kasiruta Barat Sub District can be food suppliers to Kasiruta Timur
Sub District while Bacan Timur Selatan Sub District can supply food to Bacan Selatan Sub District.

\section{CONCLUSION}

Sustainable food security development in South Halmahera can be done by production optimization approach and food distribution with small island basis to make sure affordable food availability and food access ability for people. The strategy of food production optimization concerns on land ability 
and compatible in order to maintain sustainable resource utilization and ecological function as well as the ability of independently fulfilling food needs. Distribution optimization strategies are done by optimizing region production ability so that food distribution pattern which is efficient with intra and among small islands is able to be reached.

Total projection of optimum land use for TPLB, TPLK, and TPT can fulfil optimum land needs to produce 6 food crops in South Halmahera. Surplus total of land availability to develop TPLB in Gane Timur Sub District is as much as 5,159.2 ha. Availability of land area for optimizing TPLK and TPT development land can meet optimal land needs in South Halmahera, as much as 34,834.9 and 21,971.0 ha. However, there is deficit in food crops fulfilment balance from land optimize result to develop TPLK and TPT in sub district area.

Food distribution among small island needs to fulfil balance deficit on food needs fulfilment (Picture 3). This distribution is needed for rice needs fulfilment. Rice is distributed in the production centre in Gane Timur Sub District to rice storage centre in every small islands. Rice storage is done by empowering port warehouse so that rice distribution can be done with economic volume from production centre, considering rice demand frequency in each sub district is relatively low. Then, rice distribution from storage centre to every small island is done by optimizing sea transportation service by the ships. Transportation mode will be determined according to the demand volume in each storage place (Ralahalu, dkk, 2013). In this case, people ship can be used for distributing food crops in each small island.

\section{ACKNOWLEDGE}

This research is supported by Assessment Institute for Agricultural Technology in North Maluku through the activity of Policy Analysis Supporting Regional Development 2016.

\section{REFERENCES}

Absari, U.D. 2007. Perencanaan Produksi Pangan Berdasarkan Daya Dukung Pangan Wilayah untuk Memenuhi Kebutuhan Konsumsi Pangan Penduduk di Kabupaten Nganjuk, Propinsi Jawa Timur. Tesis. Sekolah Pascasarjana Institut Pertanian Bogor.Bogor.

Adrianto L. and Y. Matsuda. 2004. Study on assessing economic vulnerability of small island regions. Environment Development and Sustainabilityi. 6: 317-336.

Arsyad, S. 2012. Konservasi Tanah dan Air. Edisi Kedua. Penerbit IPB Press. Bogor. Hal. 303344.
Azahari, D.H. 2008. Membangun kemandirian pangan dalam rangka meningkatkan ketahanan nasional. J.Analisis Kebijakan Pertanian. 6 (2): 174-195.

Bantacut, T. 2013. Pembangunan Ketahanan Ekonomi dan Pangan Perdesaan Mandiri Berbasis Nilai Tambah. J. Pangan Media Komunikasi dan Informasi. 22 (2): 181-195.

BKP (Badan Ketahanan Pangan). 2009. Food Insecurity and Vulnerability Atlas. Food Security Agency-Ministery of Agriculture. Kementerian Pertanian. Jakarta.

BPS(Badan Pusat Statistik). 2015. HalmaheraSelatan dalam Angka 2015. Badan Pusat Statistik Kabupaten Halmahera Selatan. Labuha-MalukuUtara.

BPS(Badan Pusat Statistik). 2013. Sensus Pertanian Halmahera Selatan. Badan Pusat Statistik Kabupaten Halmahera Selatan. LabuhaMaluku Utara.

Connell, J. 2015. Food security in the island Pacific: Is Micronesia as far away as ever?. Reg Environ Change.15:1299-1311.

Dahuri, R. 2008. Paradigma Baru Pembangunan Indonesia Berbasis Kelautan. IPB Press. Bogor.

Departemen Kesehatan(Depkes). 1996. Pedoman Survei Konsumsi Gizi Tingkat Kecamatan. Ditjen Pembinaan Masyarakat. Direktorat Bina Gizi Masyarakat. Departemen Kesehatan. Jakarta.

Djaenudin D, H. Marwan, H. Subagjo, A. Hidayat. 2003. Petunjuk Teknis Evaluasi Lahan untuk Komoditas Pertanian. Pusat Penelitian Tanah dan Agroklimat. Departeman Pertanian Republik Indonesia. Bogor

Hardinsyah, S. Madanijah, Y. F. Baliwati. 2002. Analisis Neraca Bahan Makanan dan Pola Pangan Harapan untuk Perencanaan KetersediaanPangan. PSKPG-IPB dan Pusat Pengembangan Ketersediaan Pangan. Departemen Pertanian. Jakarta.

Hay, J.E. and N. Mimura. 2013. Vulnerability, risk and adaptation assessment methods in the pacific islands region: past approaches, and considerations for the future.Sustain Sci. 8: 391-405. 
Jinca, M. Y. 2009. Keterpaduan sistem jaringan antar-moda transportasi di pulau Sulawesi. Jurnal Transportasi. 9 (3).

Lokollo, J. A., 2012. Kajian Model Gugus Pulau Dalam Pengembangan Wilayah Kepulauan Di Kabupaten Maluku Tenggara Barat Provinsi Maluku. Disertasi. Sekolah Pascasarjana. Institut Pertanian Bogor. Bogor.

ketahanan pangan. Seminar Nasional "Kebijakan dan Aplikasi Teknologi Informasi dan Komunikasi untuk Peningkatan Daya Saing Agribisnis Indonesia. Himpunan Informatika Pertanian Indonesia-Insitut Pertanian Bogor. 6-7 Agustus 2009. Bogor.

Pelling, M. and J.I. Uitto. 2001. Small island developing states, natural disaster vulnerability and global change. Environmental Hazards. 3 (2): 49-62.

Pimentel, D. and M. Burgess. 2013. Soil Erosion Threatens Food Production.J. Agriculture.3, 443-463.

Rachmaningsih, T. 2012. Ketahanan Pangan Di Kawasan Timur Indonesia. Tesis. Sekolah Pascasarjana Institut Pertanian Bogor. Bogor.

Ralahalu, K. A., Jinca, M. Y, Siahan, L. D., dan Sihaloho, A. 2013. Pembangunan Transportasi Kepulauan di Indonesia. Brilian Internasional. Jakarta.

Ridhwan, M.H.A., M.N. Ibrahim, F. Indawan, I. Karlina. 2012. Perdagangan Antardaerah, Distribusi, Transportasi, Dan Pengelolaan Stok Komoditas Pangan Strategis di Indonesia. Working Paper. Bank Indonesia. Jakarta.
Manuwoto, S. dan Martianto, D. 2008. Refleksi Empat Puluh Tahun Pengembangan Penganekaragaman Pangan: Lessorns Learner and What Have To Be Done. Forum Kerja Penganekaragaman Pangan. Bogor.

Mustafril, B. Setiawan, Y.J. Purwanto, L.B. Prasetyo, dan D. Martianto, 2009. Pengembangan perangkat lunak optimalisasi pemanfaatan sumberdaya hayati untuk

Ridhwan, M.H.A., I. Karlina, Yanfitri. 2012.Kajian pangan strategis: faktor determinasi variasi harga antar daerah. Working Paper. Bank Indonesia. Jakarta.

Sudaryanto, T. dan I. W. Rusastra. 2008. Kebijakan strategis usaha pertanian Dalam rangka peningkatan produksi Dan pengentasan kemiskinan. J. Litbang Pertanian. 25(4).

Sumarlin. 2009. Analisis Kebutuhan Luas Lahan Pertanian Pangan dalam Pemenuhan Kebutuhan Pangan Penduduk Kabupaten Lampung Barat. Tesis. Bogor: Sekolah Pascasarjana Institut Pertanian Bogor.

Survey Sosial Ekonomi Rumah Tangga Tahun (Susenas). 2014. Badan Pusat Statistik Pusat. Jakarta.

Widiatmaka, W. Ambarwulan, A. Sutandi, K. Murtilaksono, K. Munibah and U. Daras. 2015. Suitable and available land for cashew (Anacardium occidentale L.) in the island of Lombok, Indonesia. Journal of Applied Horticulture. 17 (2): 129-139.

Widiatmaka, Ambarwulan, W., Firmansyah, I., Munibah, K. 2014. Land suitability and dynamic system modelling to define priority areas of soybean plantation in paddy fields in karawang, west java. Argrivita. 36(3). 
